\title{
Contribution of Somatic Cell-Associated Activation of Plasminogen to Caseinolysis Within the Goat Mammary Gland
}

\author{
M. H. Weng, ${ }^{*}$ C. J. Chang, ${ }^{* 1}$ W. Y. Chen, ${ }^{*}$ W. K. Chou, ${ }^{*}$ H. C. Peh, ${ }^{*}$ M. C. Huang, ${ }^{*}$ \\ M. T. Chen, $\dagger$ and H. Nagahata‡ \\ *Department of Animal Science, National Chung Hsing University, Taichung, Taiwan, Republic of China, 402 \\ †Department of Biological Engineering, Da Yeh University, Chung Hwa, Taiwan, Republic of China, 555 \\ łDepartment of Animal Health, School of Veterinary Medicine, Rakuno Gakuen University, Ebetsu, Hokkaido, Japan, 069-8501
}

\begin{abstract}
Functional regression of the mammary gland is partly reflected by proteolysis of milk protein and tissue protein. The involvement of the plasminogen activation system in degradation of milk protein and mammary tissue damage has been demonstrated under inflammatory conditions. In this study, mammary secretion from 23 dairy goats primarily grouped as lactation (milking twice daily) or involution (milking once daily or less) was used to determine the ratio of gravityprecipitated casein to total milk protein (casein ratio) as an index of caseinolysis, and activities of components of plasminogen activation system as well as their expressions on somatic cells. Based on the casein ratio, lactation goats were subcategorized as very active ( 71.8 $\pm 1.0 \%)$ or less active $(29.9 \pm 1.0 \%)$ in mammary function; involution goats were subcategorized as gradual $(21.7 \pm 1.0 \%)$ or acute $(5.9 \pm 0.2 \%)$ involution. This result suggests that caseinolysis occurred during regular lactation as well as during involution. On the other hand, activities of components of the plasminogen activation system in mammary secretion were increased along with the decreasing casein ratio, in contrast to the similar activities of their counterparts in circulation throughout various mammary statuses. Correlation analysis between casein ratio and activities of plasminogen activation system of goat milk indicated a significant negative relationship for plasmin $(r=-0.64)$, plasminogen $(r=-0.69)$, and urokinase-type plasminogen activator ( $\mathrm{uPA} ; \mathrm{r}=-0.78$ ) during involution but not during lactation. As for the cellular components of plasminogen activation system, there was an increase in immunoreactivity on somatic cells toward both monoclonal antibodies of human UPA and human uPA receptor under involution conditions suggesting their upreg-
\end{abstract}

Received June 2, 2005.

Accepted December 20, 2005.

${ }^{1}$ Corresponding author: crchang@mail.nchu.edu.tw ulation relative to lactation condition. Collectively, these results suggest that plasminogen activation system within the mammary gland differentially contribute to milk caseinolysis along the various stages of goat lactation. Meanwhile, a somatic cell-mediated local elevation of plasmin activity may be committed to extensive caseinolysis during involution.

Key words: plasminogen activation system, caseinolysis, mammary involution, somatic cell

\section{INTRODUCTION}

Remodeling of mammary tissue progresses continuously throughout lactation especially after peak yield and is irrelevant to conception despite the fact that conception itself can accelerate the progression (Akers, 2002). An optimized dry period of approximately 40 to $60 \mathrm{~d}$ in cows not only ensures better nutritional status for the dam and developing embryo, but also benefits the mammary gland and the following lactation (Annen et al., 2004; Grummer and Rastani, 2004). During the dry period, mammary cell regeneration and tissue remodeling proceed to enhance the replacement of senescent alveolar cells before the next lactation (Capuco et al., 1997).

Most data on biochemical and physiological aspects of mammary involution have been derived from postweaning rodents and acute involuting gland of dairy ruminants following dry-off. By $48 \mathrm{~h}$ after removal of the suckling pup in rats, widespread apoptosis was observed for mammary epithelial cells, in which expression of milk component-related genes was reduced, and tissue proteases were activated (Akers, 2002). On the other hand, apoptotic mammary epithelial cells were observed in both dairy goats and cattle during active lactation (Quarrie et al., 1994; Wilde et al., 1997).

Plasmin (EC 3.4.21.7) is the predominant endogenous proteolytic enzyme in milk of various species. The level of plasmin in milk varies with season, breed, stage of lactation, inflammatory condition of mammary gland, and storage of milk (Benslimane et al., 1990; Politis, 1996; Tonner et al., 2000; Coulon et al., 2002). 
Table 1. Functional status of mammary gland of experimental goats defined based on milking frequency and casein ratio

\begin{tabular}{|c|c|c|c|c|c|c|c|}
\hline \multirow{2}{*}{$\begin{array}{l}\text { Status of } \\
\text { mammary gland }\end{array}$} & \multirow{2}{*}{$\begin{array}{l}\text { No. of } \\
\text { goats }\end{array}$} & \multirow[b]{2}{*}{ Milkings/d } & \multicolumn{2}{|c|}{ Milk protein $(\mathrm{mg} / \mathrm{mL})$} & \multicolumn{2}{|c|}{$\begin{array}{c}\text { Casein ratio }{ }^{1} \\
(\% \text { of milk protein) }\end{array}$} & \multirow[b]{2}{*}{ Range } \\
\hline & & & Mean & $\mathrm{SE}$ & Mean & $\mathrm{SE}$ & \\
\hline Very active & 5 & 2 & 29.6 & 0.9 & 71.8 & 1.0 & $61.0-82.0$ \\
\hline Less active & 7 & 2 & 28.6 & 0.3 & 29.9 & 1.0 & $20.2-54.2$ \\
\hline Gradual involution & 3 & 1 & 32.2 & 2.9 & 21.7 & 1.0 & $19.0-26.2$ \\
\hline Acute involution & 8 & Stasis & 38.7 & 1.4 & 5.9 & 0.2 & $2.3-10.1$ \\
\hline Status effects & & & $\mathrm{NS}^{2}$ & & $P<0.05$ & & \\
\hline
\end{tabular}

${ }^{1}$ Casein ratio: casein was precipitated from fresh mammary secretions after centrifugation at $100,000 \times$ $g$ and $4^{\circ} \mathrm{C}$ for $2 \mathrm{~h}$.

${ }^{2} \mathrm{NS}=$ No significant difference $(P>0.05)$ among status.

Plasmin is converted from the zymogen plasminogen by tissue-type plasminogen activator (tPA; EC 3.4.21.68) or urokinase-type plasminogen activator (uPA; EC 3.4.21.73). Both plasminogen activators are inhibited physiologically mainly by plasminogen activator inhibitor-1 (Heegaard et al., 1994). Overall activity of plasmin is presumed to be a compromised outcome of the actions of activators and inhibitors. Similar to the characteristic affinity to the blood component fibrin (Kasai et al., 1985), plasmin, plasminogen, tPA, and uPA bind to casein micelles through their kringle structure (Politis, 1996). This association provides an efficient mechanism of proteolysis on the target protein. Consequently, casein-associated activities of the plasminogen activation system have been determined to reflect overall activity in milk (Heegaard et al., 1994; Baldi et al., 2002).

Plasmin proteolysis is involved in a variety of normal and pathological processes that require cell migration and tissue remodeling. During clinical or endotoxininduced mastitis, plasmin participates in the degradation of milk proteins, leading to $\beta$-casein cleavage (Moussaoui et al., 2002), greater proteose peptone concentration, and lower curd yield (Leitner et al., 2004a,b). Plasmin is also involved in mammary tissue damage during endotoxin-induced mastitis in dairy cows (Mehrzad et al., 2005). Plasminogen activation cascade through the mediation of the uPA-uPA receptor (UPAR) complex efficiently focalizes proteolysis of migrating cells such as monocytes, macrophages, and granulocytes to degrade the extracellular matrix and basement membrane proteins (Solberg et al., 2001). However, no direct evidence for the involvement of immune cell-associated uPA-uPAR complex in mammary gland involution has been presented. We demonstrate here that the plasminogen activation system differentially participates in mammary regression during lactation and involution, whereas significant contribution of systemic origin was excluded. Milk cells were found to contribute to the activation of plasminogen system during involution.

\section{MATERIALS AND METHODS}

\section{Materials}

Human plasmin (cat. no. 421), human uPA 2-chain (cat. no. 128), monoclonal antibody against human uPA $\beta$-chain (cat. no. 394), monoclonal antibody against human uPAR domains 2 and 3 (cat. no. 3937), plasmin chromogenic substrate Spectrozyme PL (cat. no. 251), and uPA chromogenic substrate Spectrozyme UK (cat. no. 244) were purchased from American Diagnostica Inc. (Greenwich, CT). Thrombin and Nonidet P-40 were products of Calbiochem EMD Biosciences Inc. (Darmstadt, Germany). Horseradish peroxidase-labeled goat anti-mouse IgG, PolyScreen polyvinylidene difluoride transfer membrane, and Western Lightning Chemiluminescence Reagent Plus were from Perkin-Elmer Life Sciences (Boston, MA). BioMax film was a product of Eastman Kodak Company (Rochester, NY). Plasminogen, fibrinogen, gelatin, Hank's balanced salts solution with calcium and magnesium, Dulbecco's PBS without calcium and magnesium, aprotinin, cystatin, leupeptin, pepstatin, Tween 80 , and other chemicals were supplied from Sigma-Aldrich Chemical Co. (St. Louis, MO) at the highest grades available. Protein determining kit, electrophoresis reagents, and chemicals for cell isolation and homogenization were from BioRad Laboratories Inc. (Hercules, CA), Amersham-Pharmacia Biosciences (Uppsala, Sweden), Merck (Darmstadt, Germany), BDH Chemicals Inc. (Poole, UK), and United States Biological (Swampscott, MA) at cell culture or analytical grades. All animal care practices and experimental procedures complied with the guidelines of the Animal Welfare Committee of National Chung Hsing University. 


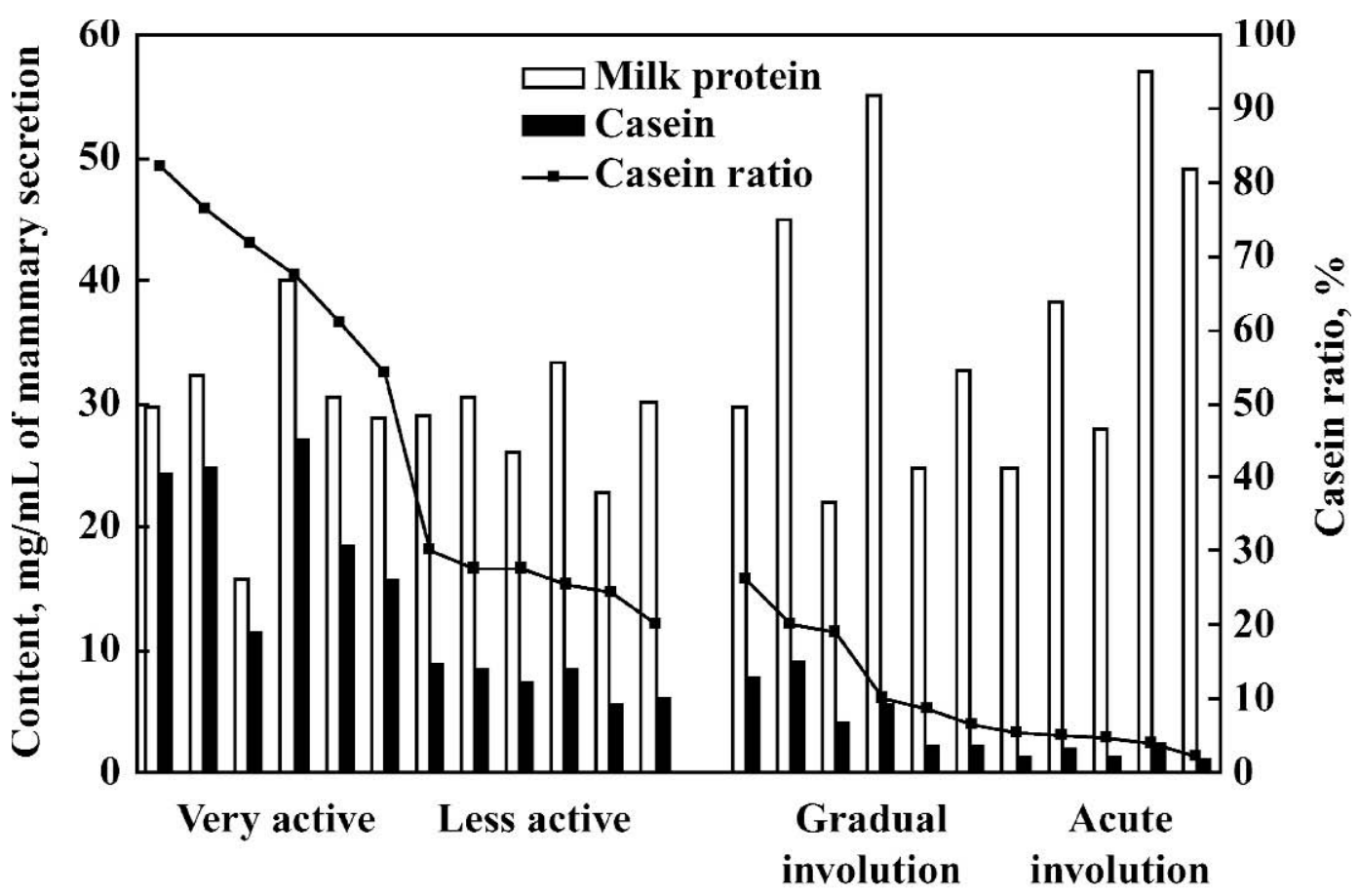

\section{Status}

Figure 1. Contents of total protein and casein in mammary secretion of individual goats aligned in descending order of casein ratio. Goats were blocked according to milking frequency in which very active and less active goats were milked twice daily, gradual involution goats were milked once daily or less, and goats in acute involution were suspended from milking for at least 1 wk. Casein was precipitated from skim milk by centrifugation at $100,000 \times g$ for $1 \mathrm{~h}$ at $4^{\circ} \mathrm{C}$.

\section{Animals and Samples}

Samples of regular milk and dry secretion were obtained from 23 dairy goats (Capra ibex ibex) raised in herd of Department of Animal Science, National Chung Hsing University (Taichung, Taiwan) from January to June 2003. Feeding and management were described previously (Tian et al., 2005). Goats were hand-milked twice a day at regular intervals until milk yields declined to about one-tenth of peak production. From this point on, milking frequency was decreased to once per day until the last month of gestation when complete milk stasis was practiced. Milk samples from each animal were sent to the central laboratory of City Bureau of Animal Disease Prevention and Diagnosis (Taichung, Taiwan) for monthly examinations of total bacterial counts, SCC, and milk gross composition. Goats for the study were selected from those 60 to $150 \mathrm{~d}$ postkidding with records of peak daily milk yield $>2.5 \mathrm{~L}$, total bacterial counts $<20,000 \mathrm{cfu} / \mathrm{mL}$, and $\mathrm{SCC}<200,000$ cells $/ \mathrm{mL}$.

\section{Casein Preparation and Extraction of Components of Plasminogen Activation System}

Fifty milliliters of fore milk was aseptically collected from individual udders and transported on ice to the laboratory within 15 min. Fat was removed from milk $(2,000 \times g$ for $20 \mathrm{~min})$, and the skim milk obtained was then centrifuged $(100,000 \times g, 1 \mathrm{~h})$ to precipitate the casein. Proteases bound to casein were released by incubating the casein precipitate with $50 \mathrm{~m} M$ Tris buffer, $\mathrm{pH}$ 8.0, containing $110 \mathrm{~m} M \mathrm{NaCl}, 50 \mathrm{~m} M$-aminocaproic acid $\left(2 \mathrm{~h}, 4^{\circ} \mathrm{C}\right.$; Politis et al., 1992), and recovered by centrifugation at $100,000 \times g$ for $1 \mathrm{~h}$ at $4^{\circ} \mathrm{C}$. Measurement of protein content of skim milk, protease-containing supernatant, and the residual casein precipitate was conducted using a dye-binding kit (Bradford, 1976). The supernatant was adjusted to a final protein concentration of $0.7 \mathrm{mg} / \mathrm{mL}$ with phosphate buffer, $\mathrm{pH}$ 7.4 , containing $138 \mathrm{mM} \mathrm{NaCl}$ and $27 \mathrm{mM} \mathrm{KCl}$, and was then stored in aliquots at $-80^{\circ} \mathrm{C}$ until assay. Heparinized plasma was prepared from jugular blood concomitantly and plasma protein content was determined before use.

\section{Preparation of Milk Cells for Immunoblotting Assay of UPA and UPAR}

Fresh somatic cells were isolated from milk or mammary secretions following the procedure of Hoeben et al. (1997). Cells were first diluted (1:1 with Dulbecco's 

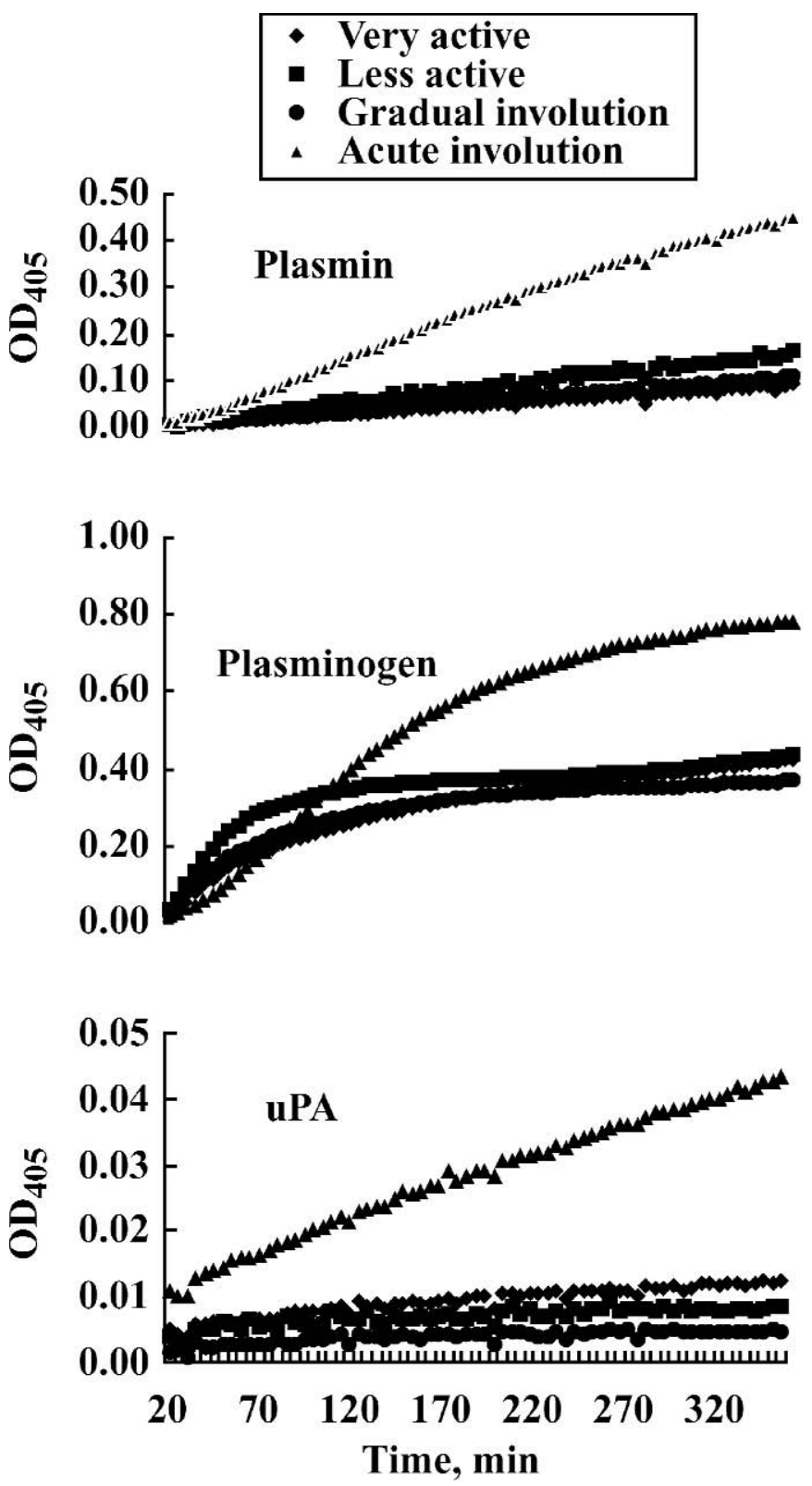

Figure 2. Kinetics of chromogenic reactions catalyzed by components of plasminogen activation system of milk. Casein-bound proteases dissociated by $50 \mathrm{~m} M$ Tris buffer, $\mathrm{pH} 8.0$, containing $110 \mathrm{~m} M$ $\mathrm{NaCl}, 50 \mathrm{~m} M \varepsilon$-aminocaproic acid at $4^{\circ} \mathrm{C}$ for $2 \mathrm{~h}$ was added into a 96well microplate and mixed with $0.4 \mathrm{mM}$ specific artificial substrates, Spectrozyme PL for plasmin and Spectrozyme UK for urokinase-type plasminogen activator (uPA), respectively, in $100 \mathrm{~mL}$ of $50 \mathrm{mM}$ Tris reaction buffer, $\mathrm{pH} 8.8$, containing $0.01 \%$ Tween 80 , and $10 \mathrm{kIU}$ of aprotinin. Reaction kinetics were recorded every 5 min for 6 h by measuring optical density at $405 \mathrm{~nm}\left(\mathrm{OD}_{405}\right)$. Plasminogen activity was recorded in the presence of 1,000 of $\mathrm{IU} / \mathrm{mL}$ of $\mathrm{uPA}$ in reaction mixture for plasmin. Point values were means of 5, 7, 3, 8 goats, respectively, for very active, less active, gradual involution, and acute involution goats, respectively.
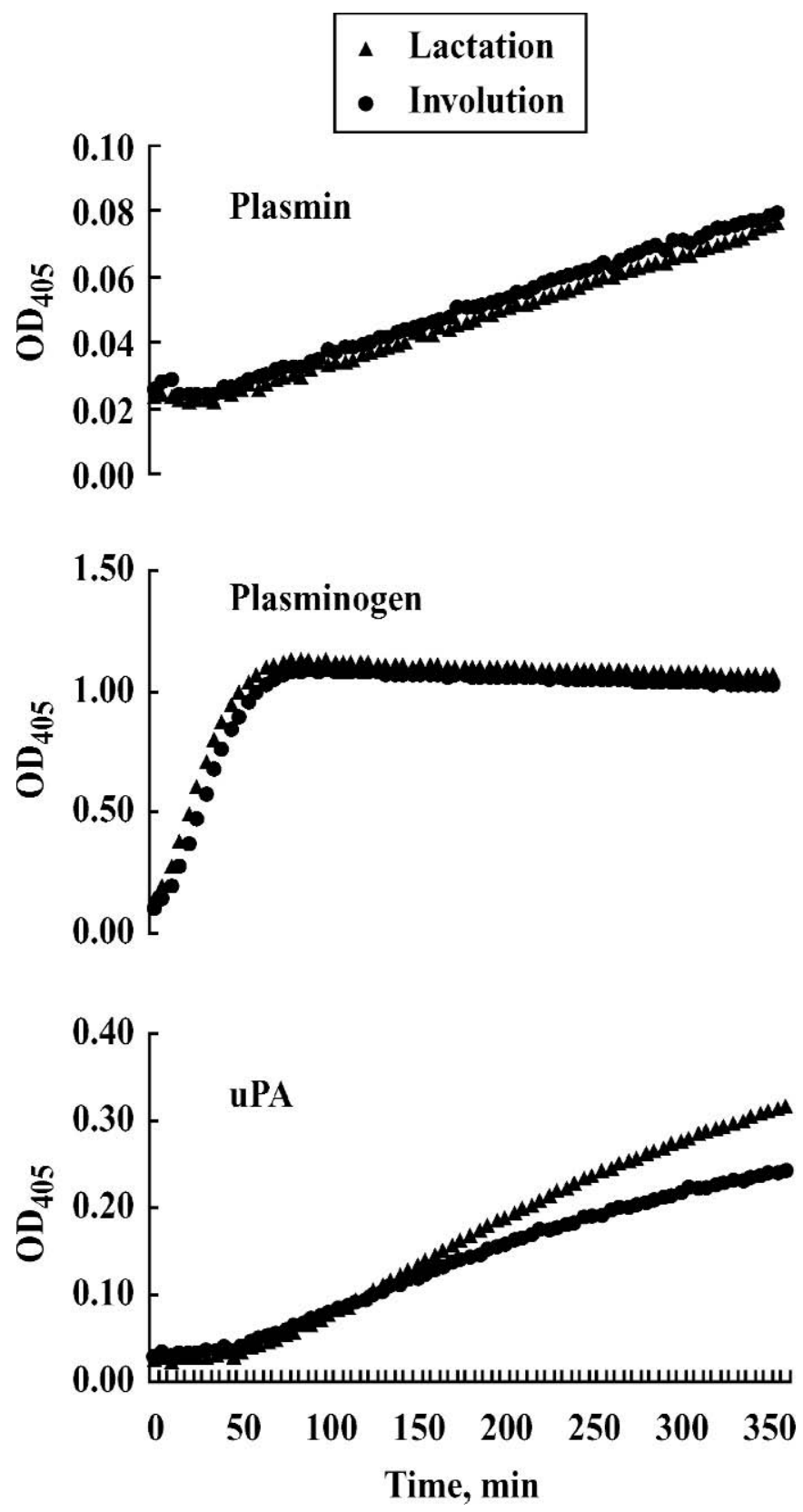

Figure 3. Kinetics of chromogenic reactions catalyzed by components of plasminogen activation system of blood. Plasma sample was added to a 96 -well microplate and mixed with $0.4 \mathrm{~m} M$ specific artificial substrates, Spectrozyme PL for plasmin and Spectrozyme UK for urokinase-type plasminogen activator (uPA), respectively, in $100 \mathrm{~mL}$ of $50 \mathrm{~m} M$ Tris reaction buffer, $\mathrm{pH} 8.8$, containing $0.01 \%$ Tween 80 , and $10 \mathrm{kIU}$ of aprotinin. Reaction kinetics were recorded every $5 \mathrm{~min}$ for $6 \mathrm{~h}$ by measuring optical density at $405 \mathrm{~nm}\left(\mathrm{OD}_{405}\right)$. Plasminogen activity was recorded in the presence of 1,000 of IU $/ \mathrm{mL}$ of uPA in reaction mixture for plasmin. Point values were means of $5,7,3,8$ goats, respectively, for very active, less active, gradual involution, and acute involution goats, respectively. 
PBS without calcium and magnesium; dilution buffer), centrifuged $\left(500 \times g, 20 \mathrm{~min}, 4^{\circ} \mathrm{C}\right)$, and washed twice with dilution buffer $\left(400 \times g, 10 \mathrm{~min}, 4^{\circ} \mathrm{C}\right)$. Milk cells were then suspended in Hanks' balanced salt solution, counted for total cell number, allocated to $1 \times 10^{7}$ cells/ vial, and lysed immediately.

Lysis buffer $50 \mathrm{~m} M$ Tris-HCl, $\mathrm{pH} 7.4$, containing $1 \%$ NP-40, $150 \mathrm{~m} M \mathrm{NaCl}$, and $1 \mathrm{~m} M$ EDTA was mixed with protease inhibitor solution ( $1 \mathrm{~m} M$ phenylmethylsulfonyl fluoride, $1 \mathrm{~m} M$ EDTA, $1 \mathrm{ug} / \mathrm{mL}$ leupeptin, $1 \mathrm{ug} /$ $\mathrm{mL}$ aprotinin, and $1 \mathrm{ug} / \mathrm{mL}$ pepstatin) and phosphatase inhibitor ( $1 \mathrm{~m} M \mathrm{NaF})$, and kept ice cold immediately before use. Cells from above were first washed with icecold PBS $\left(2,000 \times g, 10 \mathrm{~min}, 4^{\circ} \mathrm{C}\right)$, suspended with the above lysis buffer to $5 \times 10^{6}$ cells $/ \mathrm{mL}$, and kept on ice for $20 \mathrm{~min}$ with occasional shaking. Suspensions were centrifuged at $37,800 \times g$ for $15 \mathrm{~min}$ at $4^{\circ} \mathrm{C}$, and the supernatants allocated to equivalent of 5,000 original cells, and stored at $-80^{\circ} \mathrm{C}$ until assay.

\section{Activity Assay for Components of Plasminogen Activation System}

Two methodologies were applied. In the chromogenic method, artificial substrate Spectrozyme PL was used for plasmin activity assay and Spectrozyme UK was used for the uPA activity assay (Ellis and Dano, 1991; Higazi et al., 1995). In brief, triplicates of 50- $\mu \mathrm{L}$ samples were added into a 96 -well microplate, thoroughly mixed with $100 \mu \mathrm{L}$ of $50 \mathrm{mM}$ Tris reaction buffer, $\mathrm{pH}$ 8.8, containing $0.01 \%$ Tween $80,10 \mathrm{kIU}$ of aprotinin, and $0.4 \mathrm{~m} M$ Spectrozyme PL or Spectrozyme UK. Optical density at $405 \mathrm{~nm}\left(\mathrm{OD}_{405}\right)$ using microplate reader was recorded every $5 \mathrm{~min}$ for $6 \mathrm{~h}$. One unit of chromogenic activity was defined as the increment of 0.001 $\mathrm{OD}_{405}$ per min averaged over $6 \mathrm{~h}$. Plasminogen activity was estimated as the increment of plasmin activity with the addition of $1,000 \mathrm{IU} / \mathrm{mL}$ of $\mathrm{uPA}$ in the reaction mixture.

A zymographic method containing thrombin (0.25 IU/ $\mathrm{mL})$ and fibrinogen $(1.5 \mathrm{mg} / \mathrm{mL})$ in a $10 \%$ SDS-PAGE separating gel (Laemmli, 1970) was applied to reveal the phenotype of plasmin and to estimate activity. Additional plasminogen was added to the separating gel (20 $\mu \mathrm{g} / \mathrm{mL}$ ) for uPA quantification. Briefly, $16-\mu \mathrm{L}$ samples were mixed with sample buffer without boiling and were subjected to nonreducing electrophoresis. Afterwards, gels were first immersed in $2.5 \%$ Triton X-100 for $30 \mathrm{~min}$ with occasional shaking, thoroughly washed with distilled $\mathrm{H}_{2} \mathrm{O}$, then incubated with $30 \mathrm{mM}$ Tris developing buffer, $\mathrm{pH}$ 7.4, containing $200 \mathrm{mM} \mathrm{NaCl}$, $0.02 \% \mathrm{NaN}_{3}$, and $10 \mathrm{mM} \mathrm{CaCl} 2\left(37^{\circ} \mathrm{C}, 18 \mathrm{~h}\right)$. A photographic negative band with specified molecular weight was scanned and the area was integrated using Gel-Pro
Analyzer (Version 4.0 for Win 98, Media Cybernetics, Silver Spring, MD).

\section{Immunoblotting Assay for uPA and UPAR on Milk Cells}

Lysates equivalent to 5,000 milk cells were applied in duplicate to $10 \%$ SDS-PAGE. After nonreducing electrophoresis, one gel was stained with $0.5 \%$ Coomassie blue, and the other was soaked immediately in transfer buffer (48 $\mathrm{m} M$ Tris-HCl, $\mathrm{pH} 8.3$, containing $39 \mathrm{~m} M$ glycine, $20 \%$ methanol, and $0.037 \%$ SDS) for $15 \mathrm{~min}$ and subjected to protein transfer using a semidry, sandwich-type electro-transblotting method at $500 \mathrm{~mA}$ for 15 min. The transblotted PVDF membrane was incubated in blocking buffer $(20 \mathrm{~m} M$ Tris-HCl, $\mathrm{pH} 7.4$, containing $500 \mathrm{mM} \mathrm{NaCl}, 0.1 \%$ Tween 20 , and $5 \%$ skim milk powder) for $2 \mathrm{~h}$ with shaking. After washing in a blocking buffer void of skim milk for 5 min twice, the PVDF membrane was incubated overnight with primary antibodies (1:1000) in a blocking buffer containing $1 \%$ BSA instead of skim milk. The membrane was washed 3 times for $15 \mathrm{~min}$ each, and then incubated with secondary antibodies (1:5000) for $1 \mathrm{~h}$. After washing, the membrane was allowed to react for $1 \mathrm{~min}$ in a mixed enhanced luminol and oxidizing reagents were used for fluorogenic development.

\section{Statistical Analyses}

Statistical analysis was performed with the Proc GLM and Proc CORR procedures (SAS Institute, 2003). Dependent variables were casein ratio, and activities of plasmin, plasminogen, and uPA. The independent variables, functional status of mammary gland and milking frequency, were examined according to the model

$$
\mathrm{Y}_{\mathrm{ij}}=\mu+\mathrm{F}_{\mathrm{i}}+\mathrm{M}_{\mathrm{j}}+\mathrm{F}_{\mathrm{i}} \mathrm{M}_{\mathrm{j}}+\mathrm{e}_{\mathrm{ij}}
$$

where $Y_{i j}=$ dependent variable, $\mu=$ overall mean, $F_{i}=$ milking frequency, $M_{j}=$ functional status of mammary gland, $\mathrm{F}_{\mathrm{i}} \mathrm{M}_{\mathrm{j}}=$ milking frequency $\times$ functional status of mammary gland interactions, and $\mathrm{e}_{\mathrm{ij}}=$ error term (experimental variation among goats, parity, milk yield, etc.)

Comparisons among 4 statuses were conducted using the least significant differences test; $P$-values $<0.05$ were considered significant differences.

\section{RESULTS}

\section{Casein Ratio in Milk and Dry Secretion}

Casein ratio was calculated as the percentage of gravity-precipitated $(100,000 \times g)$ casein in total milk pro- 


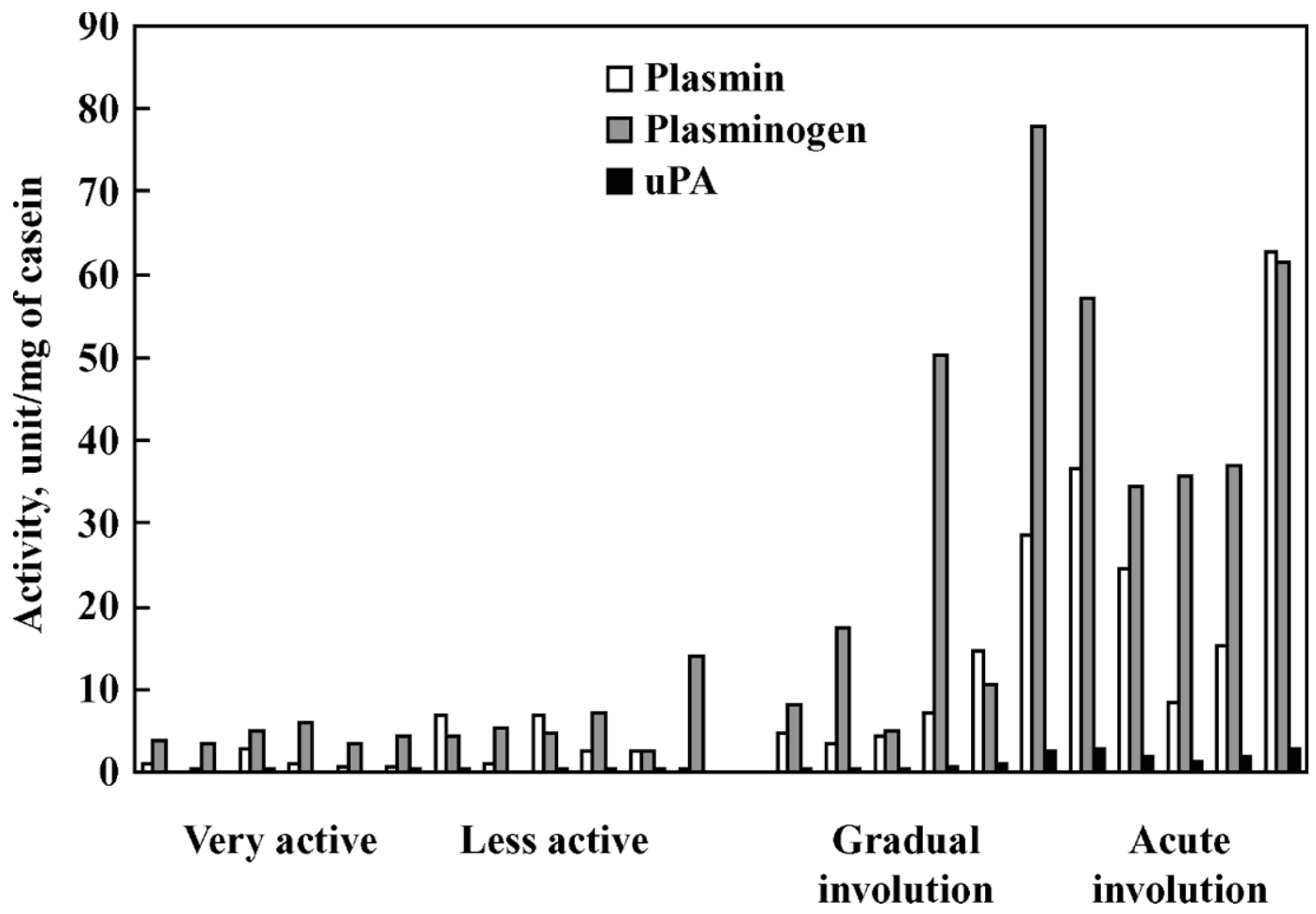

Figure 4. Chromogenic method determined specific activities of components of plasminogen activation system in mammary secretion of individual goat aligned in descending order of casein ratio. Goats were blocked according to milking frequency in which very active and less active goats were milked twice daily, gradual involution goats were milked once daily or less, and goats in acute involution were suspended from milking for at least $1 \mathrm{wk}$. Casein was precipitated from skim milk by centrifugation at $100,000 \times g$ for $1 \mathrm{~h}$ at $4^{\circ} \mathrm{C}$. Caseinbound proteases dissociated by $50 \mathrm{~m} M$ Tris buffer, $\mathrm{pH} 8.0$, containing $110 \mathrm{~m} M \mathrm{NaCl}, 50 \mathrm{~m} M$-aminocaproic acid at $4^{\circ} \mathrm{C}$ for $2 \mathrm{~h}$ was added into a 96-well microplate and mixed with $0.4 \mathrm{~m} M$ specific artificial substrates, Spectrozyme PL for plasmin and Spectrozyme UK for urokinase-type plasminogen activator (uPA), respectively, in $100 \mathrm{~mL}$ of $50 \mathrm{~m} M$ Tris reaction buffer, $\mathrm{pH} 8.8$, containing $0.01 \%$ Tween 80 , and $10 \mathrm{kIU}$ of aprotinin. Reaction kinetics were recorded every 5 min for $6 \mathrm{~h}$ by measuring optical density at $405 \mathrm{~nm}\left(\mathrm{OD}_{405}\right)$. Plasminogen activity was recorded in the presence of 1,000 of IU/mL of uPA in reaction mixture for plasmin. Point values were means of $5,7,3,8$ goats, respectively, for very active, less active, gradual involution, and acute involution goats, respectively. One unit of activity was defined as the increment of $0.001 \mathrm{OD}_{405}$ per min over the 6-h reaction period.

Table 2. Activities of plasminogen activation system components in mammary secretion of goats by functional status of mammary gland

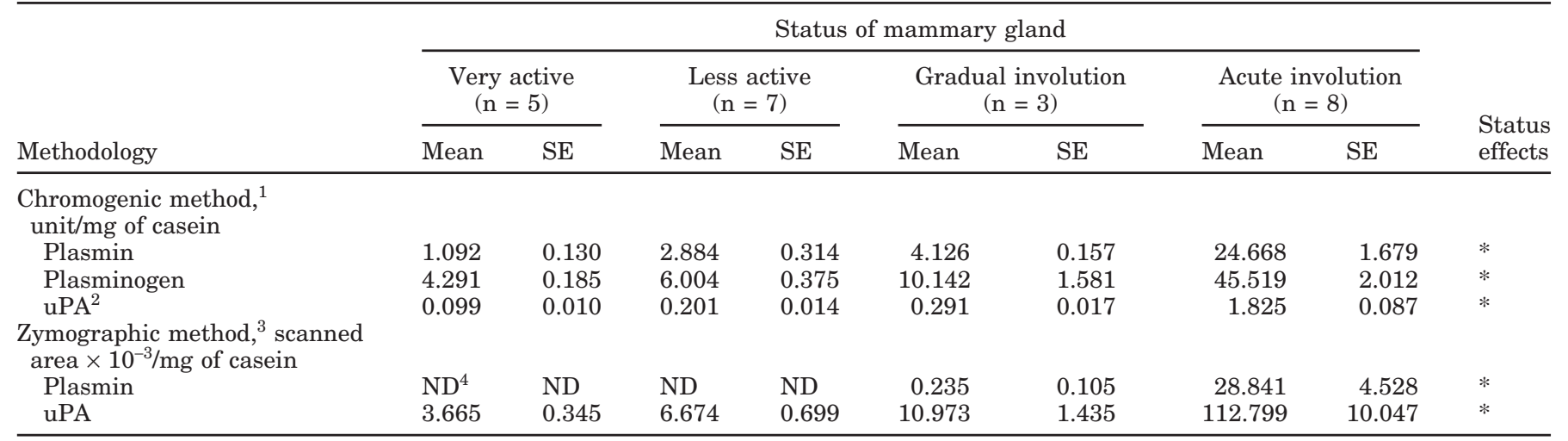

${ }^{1}$ One unit represents change of $\mathrm{OD}_{405}$ by $0.001 / \mathrm{min}$ per $\mathrm{mg}$ of casein.

${ }^{2} \mathrm{uPA}=$ Urokinase-type plasminogen activator.

${ }^{3}$ Scanned area of digest band on gels.

${ }^{4} \mathrm{ND}=$ Not detectable

$* P<0.05$. 
Table 3. Activities of plasminogen activation system components in plasma of goats by status of mammary glands

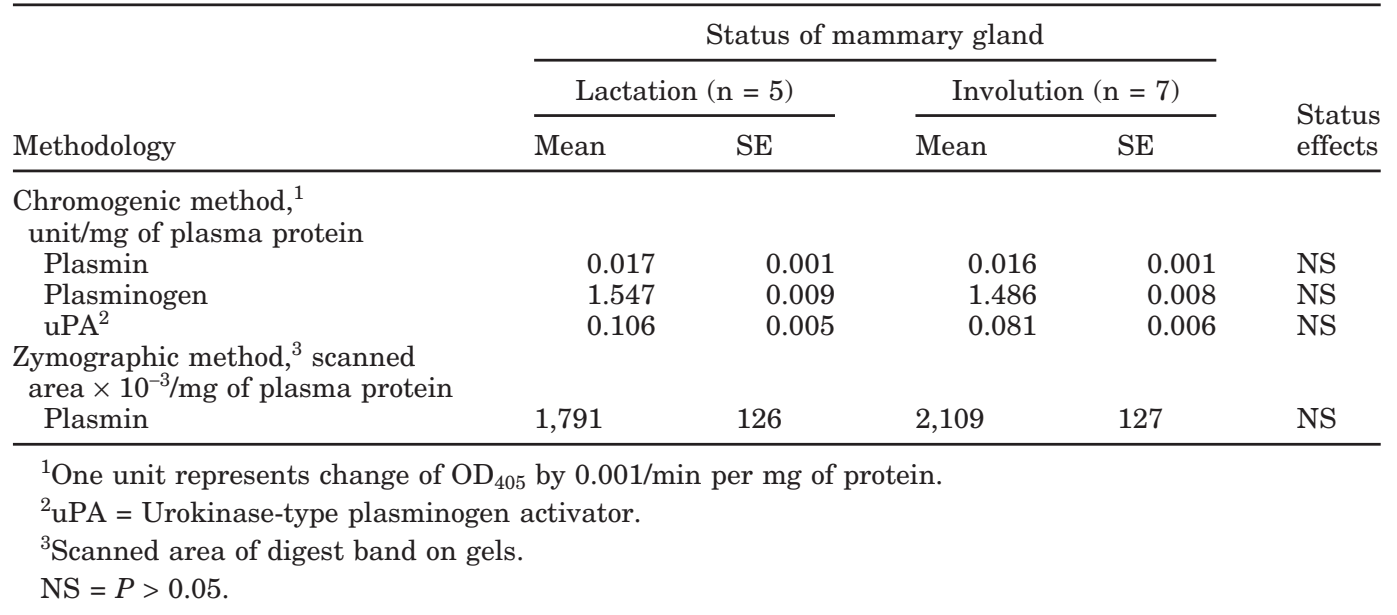

tein. Results showed that for goats in the lactation category $(\mathrm{n}=12)$, this ratio ranged from 20.2 to $82.0 \%$. To increase the uniformity of status within the lactation category, these goats were subcategorized using a casein ratio of $60 \%$ as an adequate cut-off line. Those with casein ratios above $60 \%(\mathrm{n}=5)$ were classified as very active in function of mammary gland; those with casein ratios lower than $60 \%(\mathrm{n}=7)$ were classified as less active (Table 1). Goats with milk yields less than onetenth of peak production and milking once a day were classified as in gradual involution $(n=3)$, whereas goats suspended from milking for at least $1 \mathrm{wk}$ were regarded as acute involution $(\mathrm{n}=8)$. Casein ratios ranged from 19.0 to $26.2 \%$ (mean $21.7 \%$ ) and 2.3 to $10.1 \%$ (mean $5.9 \%$ ) for goats in gradual and acute involution categories, respectively. Total milk protein and casein content of individual goats blocked by status are displayed in a histogram in descending order of casein ratio in Figure 1. Summarization of data (Table 1) indicated that although means of milk protein content were not different $(P>0.05)$ across statuses, means of casein ratio differed significantly $(P<0.05)$ among the 4 groups.

\section{Dynamics of Chromogenic Reactions}

To estimate activity and characterize enzyme property, kinetic curves of chromogenic reactions catalyzed by plasmin, plasminogen, and uPA were recorded up to $360 \mathrm{~min}$. A linear mode of chromogenic development specifically catalyzed by plasmin and uPA, respectively, was observed for both milk (Figure 2) and blood (Figure 3 ) samples. Goats under acute involution displayed the greatest plasmin- and uPA-catalyzed chromogenesis in mammary secretion than those from other 3 groups (Figure 2). As for plasminogen, estimation of plasminogen activity relied on exogenous uPA activation before adapting the plasmin measurement system. A sigmoid and saturable dynamic pattern, typical of coupled enzymatic reactions, was recorded for goats of all 4 groups. The maximum capacity of plasminogen was over twice that of plasmin within a 6 -h measurement period, suggesting that the plasmin reaction was the rate-limiting step in the coupled enzymatic system. The results showed that plasminogen in mammary secretion from goats under acute involution had a greater catalytic capacity than those of the other groups (Figure 2).

Kinetic catalysis curves of plasmin, plasminogen, and uPA in blood samples were recorded concurrently. Because samples from goats of subcategories displayed parallel kinetic curves in all 3 proteases tested (data not shown), results were pooled for lactation and involution categories only. Similar to those of milk, a linear dynamic mode for plasmin and uPA catalysis was observed, whereas plasminogen catalysis developed in a sigmoidal pattern (Figure 3). In blood samples, the maximum capacity of plasminogen catalysis was more than 1 digit greater than that of plasmin within the 6-h measurement period (Figure 3).

\section{Specific Activities of Components of Plasminogen Activation System}

For both chromogenic and zymographic analyses, no residual activity was detected in mammary secretion samples after casein precipitation (data not shown), suggesting that plasmin, plasminogen, and uPA in mammary secretions were associated with casein. Figure 4 showed the specific activities of proteases by chromogenic method of individual goats blocked by status aligned by descending casein ratios. The casein-based specific activities elevated abruptly only after milk stasis or under acute involution. Content of milk protein 


\section{(A) Mammary secretion}

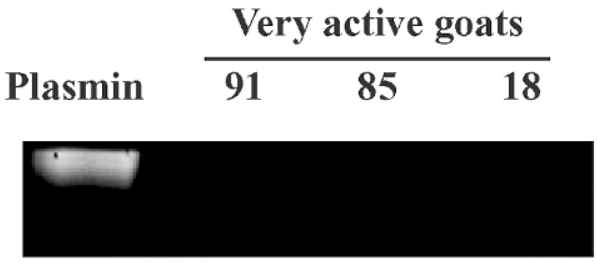

Gradual involution goats

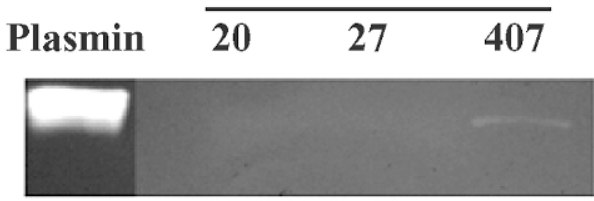

Less active goats

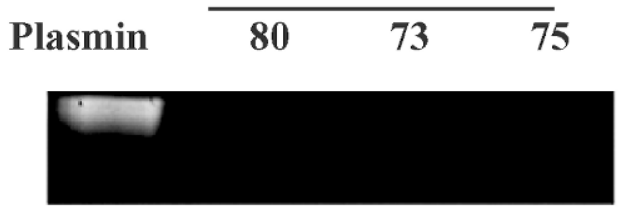

Acute involution goats

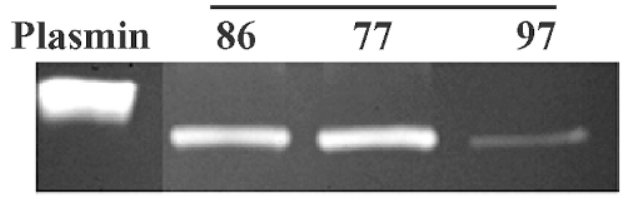

\section{(B) Plasma}

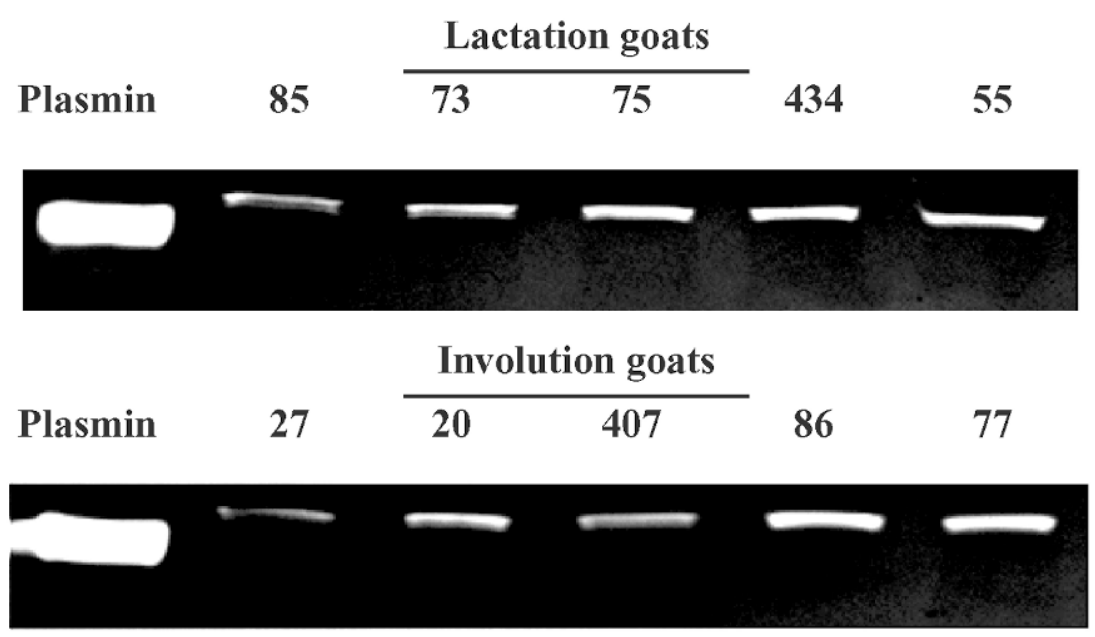

Figure 5. Representative zymograms showing the primary phenotype of plasmin in mammary secretions (A) and blood (B). Casein-bound proteases dissociated by $50 \mathrm{~m} M$ Tris buffer, $\mathrm{pH} 8.0$, containing $110 \mathrm{mM} \mathrm{NaCl}$, and $50 \mathrm{~m} M \varepsilon$-aminocaproic acid at $4^{\circ} \mathrm{C}$ for $2 \mathrm{~h}$ were applied to a $10 \%$ SDS-PAGE containing thrombin $(0.25 \mathrm{IU} / \mathrm{mL})$ and fibrinogen $(1.5 \mathrm{mg} / \mathrm{mL})$ for nonreducing electrophoresis. An $80-\mathrm{kDa}$ human plasmin was used as marker.

was not an important factor affecting the activities of these 3 proteases (data not shown). Summarization by status of the protease activities showed a significant $(P<0.05)$ status effect (Table 2$)$, in which plasmin, plasminogen, and uPA activity in acute involution were increased by approximately 24-, 12-, and 20-fold, respectively, when compared with those of very active status.

Specific activity of plasmin, plasminogen, and uPA of blood samples calculated from kinetic curves of chromogenic reaction were not significantly affected by status (Table 3; $P>0.05$ ). Systemic contribution to the elevation of plasmin, plasminogen, and uPA in mam- mary gland during involution was, therefore, not likely. Because uPA and plasmin catalyzed at different cleavage sites, these 2 proteases were not comparable in terms of activity. Also, activity of the proteases in blood was not comparable to that of the corresponding protease in mammary secretions because they were expressed on different bases. Plasminogen/plasmin ratio served as an alternative to plasminogen activation efficiency. Plasminogen/plasmin ratio in milk varied from about 2 to 4 with slight decreasing trend with advancing involution when the ratio in blood was kept well over 100. The results implied more efficient activation of plasminogen in mammary gland compared with that 

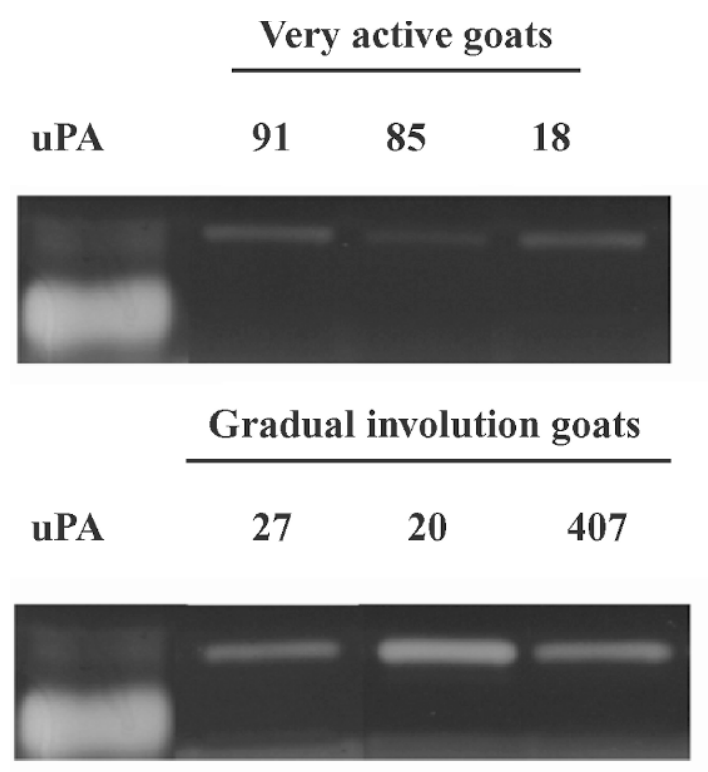

Less active goats

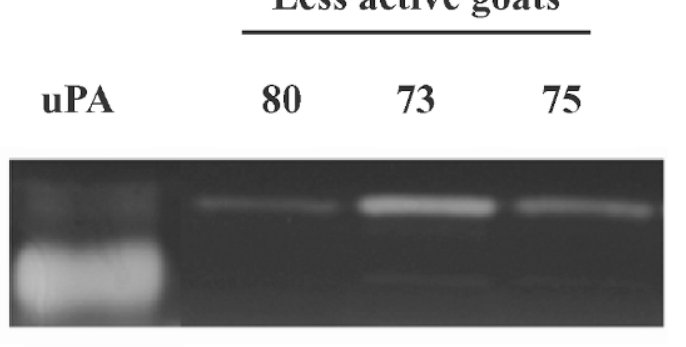

Acute involution goats

$\begin{array}{llll}\text { uPA } & 86 & 77 & 97\end{array}$

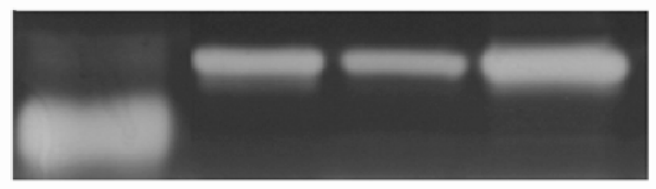

Figure 6. Representative zymograms showing the primary phenotype of urokinase-type plasminogen activator (uPA) in mammary secretions. Casein-bound proteases dissociated by $50 \mathrm{~m} M$ Tris buffer, pH 8.0, containing $110 \mathrm{~m} M$ NaCl and $50 \mathrm{~m} M \varepsilon$-aminocaproic acid at $4^{\circ} \mathrm{C}$ for $2 \mathrm{~h}$ were applied to a $10 \%$ SDS-PAGE containing thrombin $(0.25 \mathrm{IU} / \mathrm{mL})$ and fibrinogen $(1.5 \mathrm{mg} / \mathrm{mL})$ for nonreducing electrophoresis, except additional plasminogen $(20 \mu \mathrm{g} / \mathrm{mL})$ was included in the $10 \%$ SDS-PAGE. A 55-kDa human uPA was used as marker.

in circulation. Possible complications due to the presence of plasmin activator inhibitor were not tested in the present study.

Plasmin and uPA activities were also determined by a zymographic system. Representative fibrin zymograms for plasmin were displayed to justify the phenotype in milk and blood (Figure 5). In milk, a digest band with a molecular weight slightly less than the $80-\mathrm{kDa}$ human plasmin marker was found only for goats under acute involution. In blood samples, however, a digest band with molecular weight about $80 \mathrm{kDa}$ was constitutively present irrespective of status (Figure 5).

Zymography for uPA was applied only to casein dissociates (Figure 6) but not to blood samples. Only a single band with molecular weight slightly greater than the corresponding human uPA marker $(50 \mathrm{kDa})$ was observed and the band with molecular weight of $75 \mathrm{kDa}$, presumably corresponding to tPA, was absent. The intensity of the uPA band increased gradually along the progress of involution.

Figure 7 shows histograms of zymographic activities of plasmin and uPA determined by densitometric intensity for individual goats aligned in descending casein ratio. In general, the specific activity based on casein remained low except under acute involution. Again, milk protein was not an important factor to affect activities of plasmin and uPA determined by zymographic method (data not shown). Zymographic data presented in Table 2 suggested a significant $(P<0.05)$ status effect on specific activities of plasmin and uPA of mammary secretion samples. In contrast to the chromogenic method, the zymographic method failed to detect plasmin activity of mammary secretion samples in all lactating goats but gave relatively higher uPA activity of milk during involution. The zymographic method, as well as being capable of phenotyping, was more sensitive in determining uPA activity than chromogenic method, but was not as sensitive as the chromogenic method for plasmin activity.

\section{Correlations Between Activities of Plasminogen Activation System and Casein Ratio}

Goats were pooled as lactation $(\mathrm{n}=12)$ or involution $(n=11)$ before correlations were analyzed. The results show that during lactation, the casein ratio of goat milk lacked any significant $(P>0.05)$ relationship with activities of plasminogen activation system studied herein irrespective of the method applied. However, the casein ratio of dry secretion negatively correlated with chromogenic activities of plasmin $(\mathrm{r}=-0.64, P<0.05)$, plasminogen $(\mathrm{r}=-0.69, P<0.01)$, and uPA $(\mathrm{r}=-0.78, P<$ 0.01 ), but not with the corresponding activities determined by the zymographic method $(P>0.05)$.

\section{Expression of Components of Plasminogen Activation System on Milk Cells}

Western blotting results demonstrated the presence of immunoreactivity at $55 \mathrm{kDa}$ toward human uPA and 


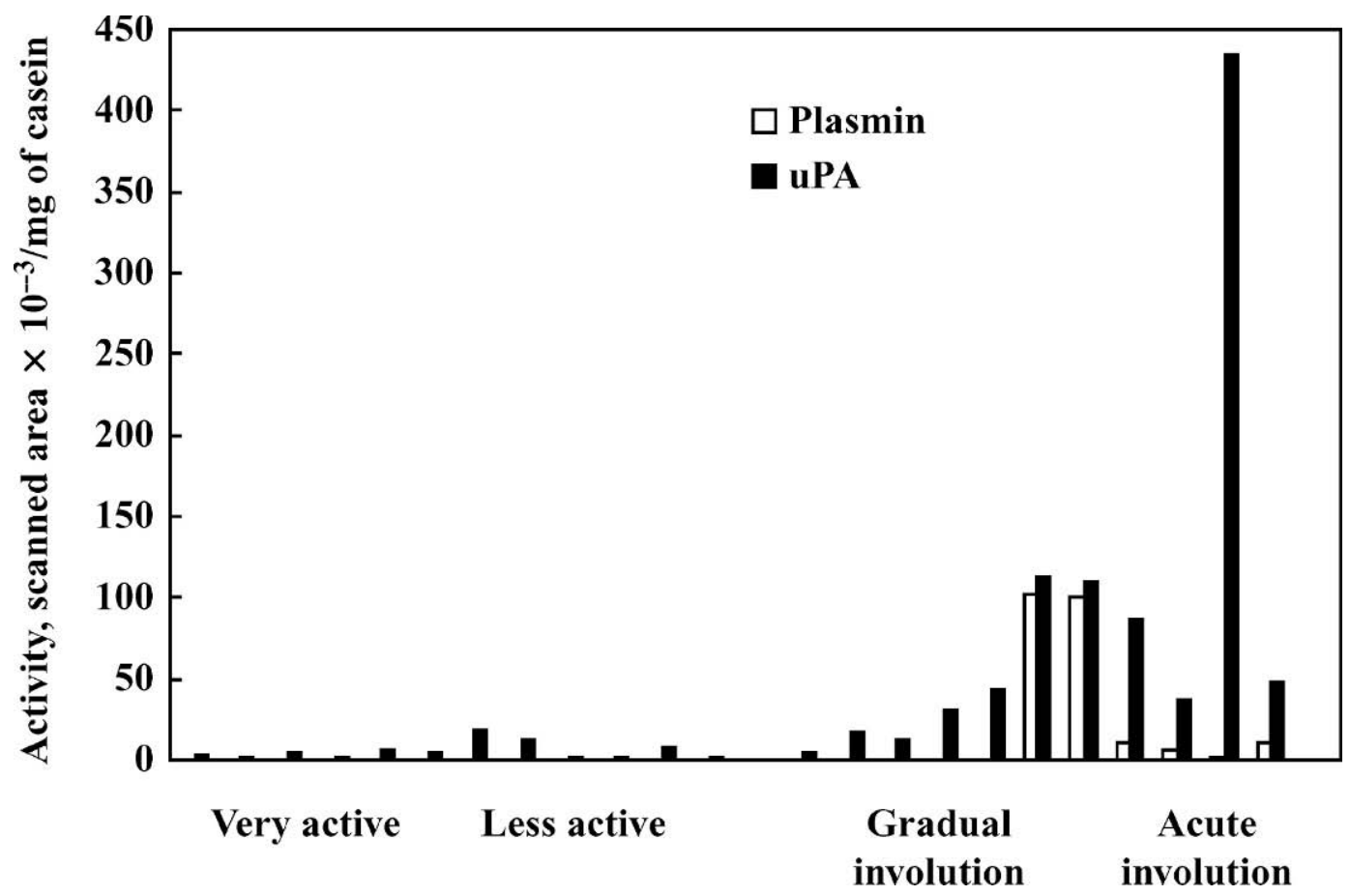

Figure 7. Specific activities of components of plasminogen activation system determined by zymographic method in mammary secretions of individual goats aligned in descending order of casein ratio. Goats were blocked according to milking frequency in which very active and less active goats were milked twice daily, gradual involution goats were milked once daily or less, and goats in acute involution were suspended from milking for at least 1 wk. Casein was precipitated from skim milk by centrifugation at $100,000 \times g$ for $1 \mathrm{~h}$ at $4^{\circ} \mathrm{C}$. Caseinbound proteases dissociated by $50 \mathrm{~m} M$ Tris buffer, $\mathrm{pH} 8.0$, containing $110 \mathrm{~m} M \mathrm{NaCl}$ and $50 \mathrm{~m} M \varepsilon$-aminocaproic acid at $4^{\circ} \mathrm{C}$ for $2 \mathrm{~h}$ were applied to a $10 \%$ SDS-PAGE containing thrombin $(0.25 \mathrm{IU} / \mathrm{mL})$ and fibrinogen $(1.5 \mathrm{mg} / \mathrm{mL})$ with (uPA) or without (plasmin) plasminogen $(20 \mu \mathrm{g} / \mathrm{mL}$ ) for nonreducing electrophoresis. The photonegative bands at $55 \mathrm{kDa}$ (uPA) and $80 \mathrm{kDa}$ (plasmin) were scanned and integrated to estimate the respective activity.

immunoreactivity at $50 \mathrm{kDa}$ toward human $\mathrm{uPAR}$ in somatic cell lysates collected from goats of all statuses. Moreover, both immunoreactivities increased during the involution stage compared with the lactation stage suggesting greater expressions of both uPA and uPAR (Figure 8).

\section{DISCUSSION}

In the present study, spontaneous regression of goat mammary gland during regular lactation was verified by noticeable caseinolysis and a relatively minor activation of plasminogen. An acute involution of goat mammary gland induced by drying off was reflected by a local extensive activation of plasminogen besides an exaggerated caseinolysis. We further explored interrelationships between caseinolysis and within-gland plasminogen activation and the role of somatic cells. Normal bovine milk readily produces proteose-peptones from caseins during incubation or storage, in which $\beta$-casein is more susceptible to hydrolysis than $\alpha_{\mathrm{s} 1}$-casein (Andrews, 1983). Virtually all constituents of the proteosepeptone fraction increased during storage and appeared to be products of the principal protease of normal milk plasmin; however, another enzyme was also involved (Andrews, 1983). A pathway of casein hydrolysis leading to the formation of small peptides was suggested as by a plasmin-like enzyme acting on specific lysine residues in casein followed by an endopeptidase-mediated or exopeptidase-mediated cleavage of the oligopeptides (Ferranti et al., 2004). In our study, although contents of total milk protein of the 12 goats milked twice daily were in the normal range, 7 were found with casein ratios less than 60\% (Table 1). This seemingly low and variable level is consistent with previously reported casein ratios (55 to 86\%) for goat milk (Renner, 1982). Gravity precipitation is, therefore, an efficient and simple method to distinguish heterogeneous casein micelles and to reveal endogenous caseinolysis.

Our observation of caseinolysis in goat milk during lactation is similar to that of Le Roux et al. (1995) and Ferranti et al. (2004). The study of Le Roux et al. (1995) demonstrated that caseinolysis within the mammary gland increased with the progression of lactation stage. They concluded that the quality of milk protein declined unavoidably during lactation regardless of SCC. Recent 


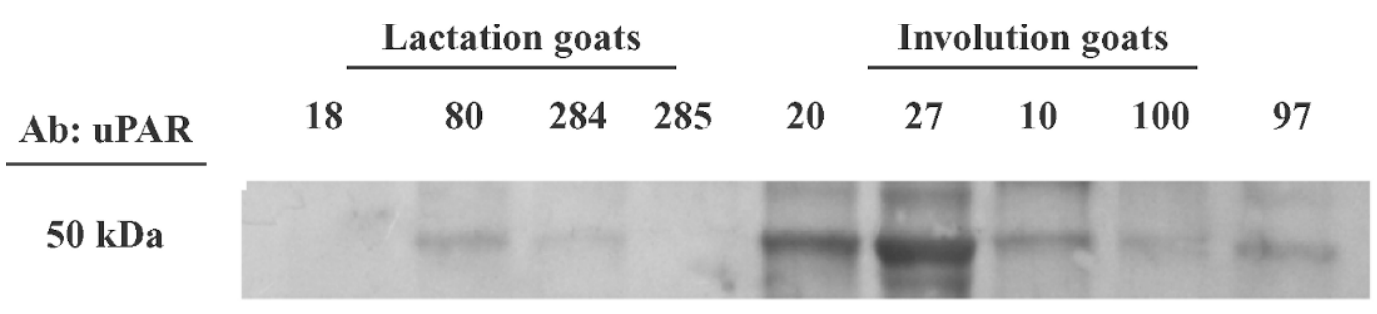

Ab: uPAR

$55 \mathrm{kDa}$

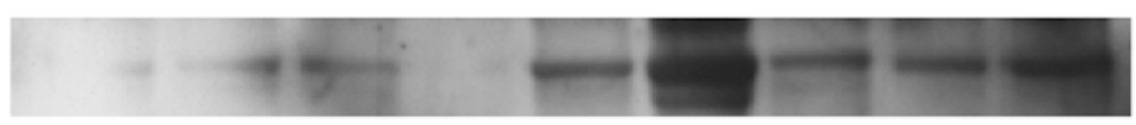

Figure 8. Expressions of urokinase-type plasminogen activator (uPA) and uPA receptor (uPAR) on somatic cells of goats representative of lactation or involution groups. Immunoblotting was conducted by hybridization of monoclonal antibodies against human uPA $\beta$-chain and human uPAR domains 2 and 3, respectively, with cell lysates. Lysates equivalent to 5,000 milk cells were applied in duplicate for 10\% SDS-PAGE.

results from studying early postpartum human milk by Ferranti et al. (2004) supported the phenomenon of spontaneous caseinolysis of normal milk. To directly verify endogenous casein proteolysis, however, laborintensive approaches might be required such as nitrogenous components series assay (Le Roux et al., 1995; Moussaoui et al., 2002), electrophoresis (Aslam et al., 1994; Aslam and Hurley, 1997), immunoblotting (Aslam and Hurley, 1997), or differential precipitation of HPLC fractionation followed by mass spectrometry sequencing (Aslam and Hurley, 1998; Silanikove et al., 2000; Ferranti et al., 2004). The potentially bioactive peptides produced from caseinolysis might be triggers for a more drastic involution process as was demonstrated by the study of Silanikove et al. (2000), in which a $\beta$-casein fraction (f1-28) produced from digest by plasmin was responsible for the stress-induced reduction in milk yield.

Our correlation results suggest that plasminogen activation system within gland undergoing involution attributed significantly to caseinolysis of mammary secretion. Meanwhile, activities of plasminogen activation system of regular milk increased slightly but not significant with decreasing casein ratio. Le Roux et al. (1995) reported a significant $(P<0.01)$ correlation between plasmin activity and casein ratio $(-0.77)$ for healthy lactating cows regardless of SCC. Differences in results between species might partly be explained by varied contribution of plasminogen activation system of systemic source, epithelial cell, or SCC. The recent work of Leitner et al. (2004a,b) found elevation of plasminogen activator and plasmin activities within mammary gland after udder infection in sheep and goats; the activities were negatively and positively correlated with con- tents of casein and proteose peptones, respectively. The results of Leitner et al. (2004a,b) are comparable to our involution results in that plasminogen activation appears to play important role in caseinolysis under unconventional mammary stage.

Our study confirmed that PA in goat milk is both casein-bound and somatic cell-associated. Because our data were calculated from chromogenic substrate Spectrozyme UK, specific for uPA instead of tPA, and on zymograms at molecular weight of $55 \mathrm{kDa}$ (that of $\mathrm{uPA}$ ), it is reasonable to specify our PA results as uPA. Actually, the presence of tPA was not detected in casein or whey of goat milk in our study. Heegaard et al. (1994) applied uPA-specific inhibitor and antihuman tPA IgG and concluded that in bovine milk, tPA and uPA were differentially localized to casein and uPAR of milk cells, respectively. Nevertheless, the results of Lu and Nielsen (1993) indicate that most of the PA activity in bovine milk is of uPA type. Because both of the studies cited above were conducted in bovine milk, results in the present study may be not comparable to their results due to species differences. None of the past studies conducted in goats in late lactation or with subclinical mastitis (Fantuz et al., 2001; Baldi et al., 2002; Leitner et al., 2004b) distinguished different types of milk PA. Only Baldi et al. (2002) specified PA activity as caseinbound. Immunoblotting assays using monoclonal antibody against human uPA in the present study suggested the presence of uPA immunoreactivity in somatic cells of goat. Because this monoclonal antibody recognizes domains not involved in binding with uPAR, we also excluded the presence of uPA/uPAR complexes or a low molecular weight uPA in goat somatic cells. This agrees with the results of Heegaard et al. (1994) 
in which a single $50-\mathrm{kDa}$ uPA band was observed in extracts of bovine milk cells according to zymographic analysis. Nevertheless, the likelihood of dissociation of uPA/uPAR complexes in the course of milk cell preparation should not be excluded in both studies.

Because the activities of components of plasminogen activation system in the circulation were similar between lactating and involution goats (Table 3 and Figure 6), we concluded that the elevated activation of plasminogen in mammary gland during involution was modulated mainly by local factors. Consequently, somatic cells appear to be one of the most important local factors involved in regulating the plasminogen activation system during involution. It is documented that degranulation of neutrophil directly releases uPA (Owen and Campbell, 1999; Le Roux et al., 2003). We demonstrated in the present study that milk cells attributed to the activation of plasminogen during involution partially by upregulating the expression of uPA and uPAR. Degranulation of neutrophils also releases neutral proteases and gelatinases, which degrade not only milk proteins but also extracellular matrix (we will discuss this in a companion manuscript). Other important contributors in regulation of plasminogen activation system in milk are various types of mammary cells. The review of Politis (1996) indicated that the plasminogen activation system in bovine mammary epithelial cells serves multiple functions including proliferation and differentiation as well as proteolysis. Moussaoui et al. (2002) suggested that plasmin was responsible for short-term caseinolysis activity in mastitis milk whereas milk cell proteases were responsible for the long-term caseinolysis. More emphasis should be placed on the role of somatic cells in modulating plasmin activity. Overall, casein proteolysis occurred spontaneously in milk during lactation of goats. Somatic cell-mediated activation of plasminogen during involution serves as an important local factor in further promoting proteolysis of casein and, possibly, mammary tissue protein. The differential role of the withingland plasminogen activation system in caseinolysis and tissue remodeling during lactation and involution is yet to be defined.

\section{ACKNOWLEDGMENTS}

This work was supported by National Science Council Grants NSC91-2313-B005-128 and NSC92-2313-B005121, Taiwan, Republic of China.

\section{REFERENCES}

Akers, R. M. 2002. Overview of mammary development. Pages 3844 in Lactation and the Mammary Gland. R. M. Akers, ed. Iowa State Press, Ames.
Andrews, A. T. 1983. Proteinases in normal bovine milk and their actions on caseins. J. Dairy Res. 50:45-55.

Annen, E. L., R. J. Collier, M. A. McGuire, and J. L. Vicini. 2004. Effects of dry period length on milk yield and mammary epithelial cells. J. Dairy Sci. 87(E. Suppl.):E66-E76.

Aslam, M., and W. L. Hurley. 1997. Proteolysis of milk proteins during involution of the bovine mammary gland. J. Dairy Sci. 80:2004-2010.

Aslam, M., and W. L. Hurley. 1998. Peptides generated from milk proteins in the bovine mammary gland during involution. J. Dairy Sci. 81:748-755.

Aslam, M., R. Jimenez-Flores, H. Y. Kim, and W. L. Hurley. 1994. Two-dimensional electrophoretic analysis of proteins of bovine mammary gland secretions collected during the dry period. J. Dairy Sci. 77:1529-1536.

Baldi, A., S. Modina, F. Cheli, F. Gandolfi, L. Pinotti, L. Baraldi Scesi, F. Fantuz, and V. Dell'Orto. 2002. Bovine somatotropin administration to dairy goats in late lactation: Effects on mammary gland function, composition and morphology. J. Dairy Sci. 85:1093-1102.

Benslimane, S., M. J. Dognin-Bergeret, J. L. Berdague, and Y. Gaudemer. 1990. Variation with season and lactation of plasmin and plasminogen concentration in Montbeliard cow's milk. J. Dairy Res. 57:423-435.

Bradford, M. M. 1976. A rapid and sensitive method for the quantitation of microgram quantities of protein utilizing the principle of protein-dye binding. Anal. Biochem. 72:248-254.

Capuco, A. V., R. M. Akers, and J. J. Smith. 1997. Mammary growth in Holstein cows during the dry period: Quantification of nucleic acids and histology. J. Dairy Sci. 80:477-487.

Coulon, J., P. Gasqui, J. Barnouin, A. Ollier, P. Pradel, and D. Pomies. 2002. Effect of mastitis and related-germ on milk yield and composition during naturally occurring udder infections in dairy cows. Anim. Res. 51:383-393.

Ellis, V., and K. Dano. 1991. Plasminogen activation by receptorbound urokinase. Thromb. Haemost. 17:194-200.

Fantuz, F., F. Polldori, F. Cheli, and A. Baldi. 2001. Plasminogen activation system in goat milk and its relation with composition and coagulation properties. J. Dairy Sci. 84:1786-1790.

Ferranti, P., M. V. Traisci, G. Picariello, A. Nasi, V. Boschi, M. Siervo, C. Falconi, L. Chianese, and F. Addeo. 2004. Casein proteolysis in human milk: Tracing the pattern of casein breakdown and the formation of potential bioactive peptides. J. Dairy Res. 71:74-87.

Grummer, R. R., and R. R. Rastani. 2004. Why reevaluate dry period length? J. Dairy Sci. 87(E. Suppl.):E77-E85.

Heegaard, C. W., L. K. Rasmussen, and P. A. Andreasen. 1994. The plasminogen activation system in bovine milk: Differential localization of tissue-type plasminogen activator and urokinase in milk fractions is caused by binding to casein and urokinase receptor. Biochim. Biophys. Acta 1222:45-55.

Higazi, A. A., R. L. Cohen, J. Henkin, D. Kniss, B. S. Schwartz, and B. Cines. 1995. Enhancement of the enzymatic activity of singlechain urokinase plasminogen activator by soluble urokinase receptor. J. Biol. Chem. 270:17375-17380.

Hoeben, D., C. Burvenich, and R. Heyneman. 1997. Influence of antimicrobial agents on bactericidal activity of bovine milk polymorphonuclear leukocytes. Vet. Immunol. Immunopathol. 56:271282.

Kasai, S., H. Arimura, M. Nishida, and T. Suyama. 1985. Proteolytic cleavage of single-chain pro-urokinase induces conformational change which follows activation of the zymogen and reduction of its high affinity for fibrin. J. Biol. Chem. 260:12377-12381.

Laemmli, U. K. 1970. Cleavage of structural proteins during assembly of the head bacteriophage T4. Nature 227:680-685.

Le Roux, Y., O. Colin, and F. Laurent. 1995. Proteolysis in samples of quarter milk with varying somatic cell counts. 1. Comparison of some indicators of endogenous proteolysis in milk. J. Dairy Sci. 78:1289-1297.

Le Roux, Y., F. Laurent, and F. Moussaoui. 2003. Polymorphonuclear proteolytic activity and milk composition change. Vet. Res. 34:629-645. 
Leitner, G., M. Chaffer, A. Shamay, F. Shapiro, U. Merin, E. Ezra, A. Saran, and N. Silanikove. 2004a. Changes in milk composition as affected by subclinical mastitis in sheep. J. Dairy Sci. 87:46-52.

Leitner, G., U. Merin, and N. Silanikove. 2004b. Changes in milk composition as affected by subclinical mastitis in goats. J. Dairy Sci. 87:1719-1726.

Lu, D. D., and S. S. Nielsen. 1993. Isolation and characterization of native bovine milk plasminogen activators. J. Dairy Sci. 76:3369-3383.

Mehrzad, J., C. Desrosiers, K. Lauzon, G. Robitaille, X. Zhao, and P. Lacasse. 2005. Proteases involved in mammary tissue damage during endotoxin-induced mastitis in dairy cows. J. Dairy Sci. 88:211-222.

Moussaoui, F., I. Michelutti, Y. Le Roux, and F. Laurent. 2002. Mechanisms involved in milk endogenous proteolysis induced by a lipopolysaccharide experimental mastitis. J. Dairy Sci. 85:25622570.

Owen, C. A., and E. J. Campbell. 1999. The cell biology of leukocytemediated proteolysis. J. Leukoc. Biol. 65:137-150.

Politis, I. 1996. Plasminogen activator system: Implications for mammary cell growth and involution. J. Dairy Sci. 79:1097-1107.

Politis, I., D. M. Barbano, and R. C. Gorewit. 1992. Distribution of plasminogen and plasmin in fractions of bovine milk. J. Dairy Sci. 75:1402-1410.
Quarrie, L. H., C. V. P. Addey, and C. J. Wilde. 1994. Local regulation of mammary apoptosis in the lactating goat. Biochem. Soc. Trans. 22:178S

Renner, M. 1982. Milk and Milk Products in Human Nutrition. Vdkswirtsch, Verlag GmbH Publ. Munich, Germany.

SAS Institute. 2003. SAS/STAT User's Guide. Release 6.12. SAS Institute Inc., Cary, NC.

Silanikove, N., A. Shamay, D. Shinder, and A. Moran. 2000. Stress down regulates milk yield in cows by plasmin induced $\beta$-casein product that blocks $\mathrm{K}^{+}$channels on the apical membranes. Life Sci. 67:2201-2212.

Solberg, H., M. Ploug, G. Hoyer-Hansen, B. S. Nielsen, and L. R. Lund. 2001. The murine receptor for urokinase-type plasminogen activator is primarily expressed in tissues actively undergoing remodeling. J. Histochem. Cytochem. 49:237-246.

Tian, S. Z., C. J. Chang, C. C. Chiang, H. C. Peh, M. C. Huang, J. W. Lee, and X. Zhao. 2005. Comparison of morphology, viability, and function between blood and milk neutrophils from peak lactating goats. Can. J. Vet. Res. 69:39-45.

Tonner, E., G. J. Allan, and D. J. Flint. 2000. Hormonal control of plasmin and tissue-type plasminogen activator activity in rat milk during involution of the mammary gland. J. Endocrinol. 167:265-273.

Wilde, C. J., C. V. P. Addey, P. Li, and D. G. Fernig. 1997. Programmed cell death in bovine mammary tissue during lactation and involution. Exp. Physiol. 82:943-953. 